DOI: https://doi.org/10.34069/AI/2021.45.09.12

Hryhorenko, A., Musiienko, O., Boiko-Dzhumelia, V., Sakovskyi, A., \& Myrovska, A. (2021). Reconstruction as a method of crime investigation. Amazonia Investiga, 10(45), 113-119. https://doi.org/10.34069/AI/2021.45.09.12

\title{
Reconstruction as a method of crime investigation
}

\section{Реконструкція як один із методів розслідування злочинів}

Received: August 20, 2021

\section{Abstract}

The purpose of the article is to analyze the method of reconstruction as one of the general scientific methods of criminology used in the investigation of crimes. The subject of research is the method of reconstruction in forensic science. The research methodology includes the use of general scientific and special methods of scientific cognition: dialectical, historical and legal, formal and logical, comparative and legal, logical, system and structural methods, method of generalization. Research results. General scientific methods of criminology and their significance for crime investigation are considered. Reconstruction as a type of modeling method and its place in the system of forensic methods is defined. The signs of reconstruction and its features distinguishing from modeling are analyzed. The variants of reconstruction and their features are given. Practical meaning. The concept of reconstruction as an independent method of crime investigation and its implementation in the system of investigative (search) actions are proposed. Value / originality. Emphasis is placed on the need for further study of reconstruction as a special method of investigating crimes.
Accepted: September 30, 2021

Written by:

Andrii Hryhorenko ${ }^{42}$

https://orcid.org/0000-0001-7563-3660

Oleh Musiienko ${ }^{43}$

https://orcid.org/0000-0001-6533-0359

Viktoriia Boiko-Dzhumelia ${ }^{44}$

https://orcid.org/0000-0002-7017-1935

Andrii Sakovskyi ${ }^{45}$

https://orcid.org/0000-0003-0762-859X

Anna Myrovska ${ }^{46}$

https://orcid.org/0000-0001-5714-1873

\section{Анотація}

Метою статті $є$ аналіз методу реконструкції як одного із загальнонаукових методів криміналістики, що застосовується під час розслідування злочинів. Предметом дослідження $\epsilon$ метод реконструкції в криміналістичній науці. Методологія дослідження включає в себе використання загальнонаукових та спеціальних методів наукового пізнання: діалектичний, історикоправовий, формально-логічний, системноструктурний, узагальнення, порівняльноправовий. Результати дослідження. Розглянуто загальнонаукові методи пізнання криміналістики та їх значення для розслідування злочинів. Визначено поняття реконструкції як методу моделювання та його місце в системі криміналістичних методів. Проаналізовано ознаки реконструкції та їі відмінність від моделювання. Наведено різновиди реконструкції та їх особливості. Практичне значення. Визначення реконструкції як незалежного методу розслідування злочинів та іiі реалізація у системі слідчих (розшукових) дій. Цінність/оригінальність. Акцентовано увагу на необхідності подальшого дослідження

\footnotetext{
${ }^{42}$ Postgraduate Student of the Yaroslav Mudryi National Law University, Ukraine.

${ }^{43} \mathrm{Ph} . \mathrm{D}$ in Law, Associate Professor, Associate Professor of the Department of Criminalistics of the Yaroslav Mudryi National Law University, Ukraine.

${ }^{44}$ Postgraduate student of the Department of Criminalistics of the National University "Odessa Law Academy", Ukraine.

${ }^{45} \mathrm{PhD}$ in Law, Associate Professor, Director of the Educational and Scientific Institute No. 2 of the National Academy of Internal Affairs, Ukraine.

${ }^{46} \mathrm{PhD}$ in Law, Associate Professor, Professor of the Department of Criminal Sciences and Forensic Medicine of the National Academy of Internal Affairs, Ukraine.
} 
Keywords: expert, investigation (search) actions, methodology, modeling, reconstruction.

\section{Introduction}

An effective basis for crime prevention is appropriate ways to combat it, including improving their detection and investigation. This provision complies with the norms of the current Criminal Procedure Code of Ukraine (Law of Ukraine No. 4651-VI, 2012), which provides for prompt, complete and impartial investigation and trial (Article 2) on the basis of the facts and circumstances to be proved in criminal proceedings. The establishment of such facts and circumstances is carried out by criminal procedural evidentiary process, which lies in the collection, verification and evaluation of evidence (Klymchuk et al. 2021, p. 205).

Various methods of cognition, through which law enforcement agencies investigate criminal offenses, are widely used in modern criminology (the science on the laws of collection, research, evaluation and use of evidence). These methods can be divided into general, general scientific and specific ones.

The method of reconstruction (or modeling), which is often used by the investigators, is, in our opinion, one of the most important. With the help of this method it is possible to reproduce certain events, phenomena and processes that took place in the past and the establishment of which is important for the objective investigation of criminal offenses. However, the specifics of the use of the method of reconstruction in criminology in general and its place in the system of investigation (search) actions are not fully considered in scientific literature. That is why the purpose of our article is to analyze the method of reconstruction as one of the general scientific methods of criminology used in the investigation of crimes.

\section{Methodology}

The methodology of the article is based on general and special methods of scientific knowledge, the use of which is determined by the purpose, object, and subject matter of the research.

The method of hermeneutics was used in the process of studying the texts of legislative acts реконструкції як особливого методу розслідування злочинів.

Ключові слова: методологія; моделювання; подія; пізнання; криміналістика; процес відображення; слідчі (розшукові) дії.

and research materials on the issue under consideration.

Historical and legal method allows to trace the historical development of the studied phenomenon.

Formal and logical (dogmatic) method helps to analyze the norms of the current criminal procedural legislation, regulating the features on reconstruction method application and the practice of its application.

The application of logical method allows to formulate the concept of reconstruction as an independent method of crime investigation.

Legal and comparative method is used to compare the methods of reconstruction and modeling and to determine their common and distinctive features.

System and structural method is applied when identifying the types of reconstruction.

The method of generalization helped to draw relevant conclusions and suggestions.

\section{Literature Review}

The development of methodology and characterization of forensic methods is the subject matter of research by many domestic and foreign scientists.

The issues of the methodology of criminology, the process of investigation, modeling during the investigation of crimes, the problems of criminological tactics and methods were investigated in the works by Luzhin (1981a). In particular, in his work "Reconstruction in the investigation of offenses", the scientist stated that "reconstruction in the investigation has a double meaning; some types of reconstruction, such as an investigative experiment, is a tactical investigation, while the other types reconstruction of the face on the skull, reconstruction individual items, etc., have only an independent meaning. 


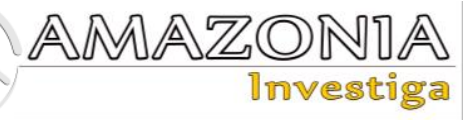

Among modern researchers who have examined the issues of forensic modeling and reconstruction is Kolodina (2016). She considers the principle of forensic reconstruction one of the specific principles of forensics in her study "Principles of forensic methodology in the investigation of crimes".

Nehrebetskyi (2018) notes that the reconstruction of the situation during on-site verification cannot be considered as a separate tactic, as only a set of tactics can ensure the realization of the goal of reconstruction.

Areshonkov (2021) examines modern methodology in terms of forensic research and their improvement by studying foreign experience. He also formulated the definition of previous forensic research, which is not procedural in nature and can be used by the carriers of such knowledge when conducting investigation (search) actions.

Siegel (2020) proves that criminalistics, which is the application of scientific methods to the recognition, collection, identification, and comparison of physical evidence generated by criminal or illegal civil activity, involves the reconstruction of such events by evaluation of the physical evidence and the crime scene.

Chisum (2007) believes that crime reconstruction is the observation of the results of an act or action then postulation of the cause of those results on the basis of physical evidence and documentation of the crime scene by competent personnel.

Paying particular attention to crime scene reconstruction Jankowski (2018) states that it is a method of solving a crime that starts with the creation of a theory of how it occurred.

Gupta et al. (2015), in their turn, investigated the issue of forensic facial reconstruction, which in their opinion, can be used to identify unknown human remains when other techniques fail. Within the research the scholars examine various methods of manual facial reconstruction and decide, which ones are the most useful.

However, the specifics of the use of the method of reconstruction in criminology in general and its place in the system of investigation (search) actions were not fully considered in these works, which led to the purpose of our article.

\section{Results and Discussion}

Any independent science, including criminology, is characterized not only by a specific subject matter and object of study, but also by special methods of research of its tasks. Under the concept of methodology we understand the doctrine of the methods of cognition and transformation of reality, the principles of organization of cognitive and transformational activities, as well as the set of methods, techniques and research tools used in any science (Tsilmak 2017, p. 23).

The methodology of criminology is not only the theory of knowledge, but also the set of methods of practical (scientific) activity. The methods are an extremely important tool of cognition; the reliability of the obtained results depends on the correct choice of a particular method. The method in the narrow sense is a "path of cognition"; in the broad sense it is the way of cognition, research or practical implementation of the algorithm of actions during the pre-trial investigation of criminal offenses (Tsilmak 2017, p. 29).

Methods of criminology are the ways to solve scientific problems in the process of forensic research. There are different groups of methods of forensic research in the scientific literature, among which we can name philosophical, specific scientific and general scientific methods (Chornous 2018, p. 452).

Philosophical (or comprehensive) methods are based on materialist dialectic, which lies in the study of objects and phenomena of reality in motion, change, development and interconnection. Specific scientific methods are used to study the objects, phenomena, events and facts that make up the subject matter of a particular science. These include forensic, criminological, biological methods, etc.

The difference between the general scientific method and other ones is that it is used in many sciences and areas of practice and is based on the provisions of formal logic. If we talk about criminology, it is used to study the event of the crime, its consequences in order to establish the composition of the crime, the circumstances of its commission, the involvement of other persons, etc. (Kiian 2017, p. 444).

The methods of obtaining and verifying information are one of the groups of general scientific methods of cognition. They are: observation, experiment, modeling, 
identification, etc. There is a division of general scientific methods into sensitive and rational and mathematical ones in some sources, but we do not agree with this view and believe that the name "methods of obtaining and verifying information" is more appropriate, given the tasks they perform.

The method of modeling should be understood as the study of any phenomena, processes or objects by studying their "model", i.e. with the help of specially created analogues, when the analysis of the object, process or phenomenon is impossible or impractical (Lukianchykov et al., 2017, p. 65). Reconstruction is a variant of modeling method. But there is an opinion that the method of reconstruction is a separate independent general scientific method (Luzhin 1981b).

It should be noted that reconstruction is a cognitive method of modeling and has a limited scope in scientific and practical activities; besides criminology, it is used in archeology, architecture, paleontology. It is believed that its origin took place in 1914 with the publication of the work by Rudolf Martin (1928), who created the program for reconstruction of the face on the skull through the study of anthropological material. His followers confirmed that the shape and proportions of the skull allow to reconstruct the muscles and soft tissues, which further reproduce the face (Rathbun 1984, p. 347). In the early 80 's of the 20th century reconstruction as a method of modeling was introduced in criminology by Luzhin (1981b).

Reconstruction in criminology is now understood as the reproduction of certain objects, processes, phenomena and actions that existed in the past, and the study of which is necessary to establish the circumstances of the crime. In the course of reconstruction the circumstances, events, processes, actions of the participants and other things that had occurred in the past are reflected (Grigorenko, 2019, p. 46).

Vasiliev (2002, p. 20) defines reconstruction as an activity that includes the current and final analysis of all collected information; reproducing the events of the past in the footsteps of the present.

Belkin (1964, pp. 83 - 84) considered reconstruction as one of the methods of crime investigation. He noted: "we are reconstructing the situation either for the purpose of its further review or to conduct an investigative experiment in artificial conditions."
The view of Ratinov (1967, p. 123) is following: "reconstruction is one of the types of modeling. This is special investigative action - an investigative experiment (reproduction of the actions, circumstances and situation of the particular event), which is essentially a simulation, but is sometimes characterized as a reconstruction.

Having analyzed scientific literature, we came to the conclusion that reconstruction is one of the methods used to detect offenses. It is applied during inspections, searches, interrogations and other investigative actions and does not replace investigation.

This method of fighting crime is endowed with a number of features that distinguish it from the method of modeling. We propose to consider the following:

- the degree of analogy (similarity): when reconstructed, the analogy is limited to the restored feature frame and is incomplete, partial; at the same time, the simulation creates an analogue of the event (object or phenomenon) with the original features present;

- direction of cognition: reconstruction is always retrospective: the lost or changed properties of an object, event or phenomenon (which were in the past) are established, or the object itself is reproduced, which at the time of the study is not a single whole; modeling can also be forward-looking - perform predictive, planning functions, etc .;

- features of the object of study: the object of reconstruction is always existing in the past or actually existing (but already changed) object of reality (event, phenomenon, object); the model can be virtual, probabilistic or hypothetical;

- level of abstraction: any model is an abstraction, i.e. is the result of an imaginary deviation from a particular phenomenon, object or its properties for highlighting the most significant features. The material component is used for reconstruction together with the information component (the elements of the original), while modeling requires just a sufficiently high level of abstraction;

- type of reflection: the process of cognition during reconstruction comes from specific to general, as the studied fragment may retain its individual features, and the task of reconstruction is to determine and restore the original appearance of the object, i.e. to 


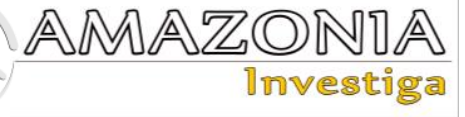

establish the most common features that will characterize of one category (group or class); the process of cognition in modeling is the opposite - from specific to general;

- features of implementation: the essence of the reconstruction is a direct study of the original, its fragments, parts; new object is not created for this purpose, unlike modeling;

- status of the model: in the process of reconstruction the model acts as the final outcome of cognition. The renewable properties are first mapped using the imagination, which are then realized in the form of indications, diagrams, tables, layout of the object itself.

Most scientists share the view that the basis for the classification of research models is the ways and means by which a method is produced. That is why there are two types of reconstruction material and ideal (mental) ones. Material reconstruction is devices, vehicles, models and other material objects that already exist, are specially created or built, and are used independently of the subject matter of knowledge. For example, this could be the closest possible creation of a scene for an investigative experiment to verify the testimony of a participant in criminal proceedings (Grigorenko, 2019, p. 46).

Material reconstruction also includes:

- model reconstruction - a tactical technique used during investigative (search) actions. It is not a kind of investigative experiment, but is used as an illustration to the conclusions of the expert.

- facial reconstruction to the skull - an independent expert study used to search for and identify a person (Herasymov 2010, p. 255), etc.

Ideal (mental) reconstruction includes various kinds of imaginary, mental, ideally existing systems, structures, constructions, study and research of which takes place in compliance with certain rules. For example, it may be the mental activity of the investigator, who models the mechanism of the crime on the basis of the facts obtained during investigation (search) actions. Such reconstruction is a powerful foundation for advancing investigative versions.

Currently, the organization "Association For Crime Scene Reconstruction (ACSR)", which was established on September 18, 1991 by forensic scientists Henry O'Hara and Charles
O'Hara (2003), is operating. They are considered the founders of the method "Crime Scene Reconstruction (CSR)" or Crime Scene Analysis (CSA).

The Author of the modification of this method on the territory of Ukraine is Afonin ("Reconstruction of the method (mechanism) of committing crime"); in the course of the application of this method he took into account the conditions of the pre-trial investigation of criminal proceedings by the National Police of Ukraine.

The content of this method is to establish the actions of the offender at the scene of the crime, their sequence or detection of staged actions, detailed study of the trace picture, systematic analysis of the information obtained and subsequent gradual reproduction of the mechanism of the crime.

Accordingly, scientists note that the method of reconstruction should be distinguished from other methods used, for example, during an investigative experiment. The investigative experiment is conducted by the investigator within the procedural limits of this investigative (search) action. The method of reconstruction should be applied by a special person - an expert analyst or reconstructor. The result of the work should be confirmed by an expert opinion (Tsilmak 2017, p. 218).

When applying the reconstruction method, the authorized expert should use only the information obtained as a result of the inspection of the scene (for example), from specialists in various fields of science and expert research, which are based on scientific methods.

It should be noted that the expert (analyst or reconstructor) should not be the specialist in all areas, as the method of reconstruction that he uses is just to establish logical, spatial, temporal relationships between the actors and the event.

\section{Conclusion}

Thus, the main purpose of the method described above is to reconstruct, i.e. to reproduce the mechanism of the crime by analyzing all the data, establishing cause-effect relationships and completing a step-by-step trace.

The disadvantages of using this method in Ukraine are: 
- differences in the application of the method of reconstruction in accordance with the rules of criminal procedure (lack of expert examination of the scene);

- lack of specialization of expert analysts (reconstructors) and proper software.

- Summarizing, we can state that forensic reconstruction is a special process of reflection, reproduction of signs of missing or altered object associated with the investigated event on imaginary depictions, descriptions, testimony of witnesses, images or physical evidence important (essential) for the investigation resulting in a material object or model similar to the original, which is a source of evidence or contributes to its receipt during investigative (search) actions and forensic examinations.

The object recovered by this method can be used for further experiments, checks, discrepancies, etc. The process of applying the method of reconstruction in the investigation of criminal offenses remains unexplored, but continues to contribute to the to the fulfilment of the investigative priorities.

\section{Bibliographic references}

Areshonkov, V. (2021). Theoretical, legal and praxeological principles of technical forensic research in the investigation of crimes. (Doctoral Dissertation). National Academy of Internal Affairs, Ukraine, http://elar.naiau.kiev.ua/handle/123456789/1 8807

Belkin, R. (1964). Experiment in investigative, judicial and expert practice. Moskow: Legal Literature.

Chisum, J. (2007). Crime reconstruction. In: The Forensic Laboratory Handbook: Procedures and Practice (pp. 63 - 77), edited by: A. Mozayani and C. Noziglia. Totowa, NJ: Humana Press Inc. http://eknygos.lsmuni.lt/springer/658/6377.pdf

Chornous, Yu. (2018). Methodological principles of forensic support of crime investigation. In the collection: Actual problems of criminology and forensic expertise of the interdepartamental scientific and practical conference. Kyiv: National Academy of Internal Affairs, pp. 450-454. http://elar.naiau.kiev.ua/bitstream/12345678 9/2841/1/\%D0\%9C\%D0\%95\%D0\%A2\%D0 $\% 9 \mathrm{E} \% \mathrm{D} 0 \% 94 \% \mathrm{D} 0 \% 9 \mathrm{E} \% \mathrm{D} 0 \% 9 \mathrm{~B} \% \mathrm{D} 0 \% 9 \mathrm{E}$
$\% \mathrm{D} 0 \% 93 \% \mathrm{D} 0 \% 86 \% \mathrm{D} 0 \% \mathrm{~A} 7 \% \mathrm{D} 0 \% 9 \mathrm{D} \% \mathrm{D} 0$ $\% 86 \% 20 \% \mathrm{D} 0 \% 97 \% \mathrm{D} 0 \% 90 \% \mathrm{D} 0 \% \mathrm{~A} 1 \% \mathrm{D} 0$ $\% 90 \% \mathrm{D} 0 \% 94 \% \mathrm{D} 0 \% 98 \% 20 \% \mathrm{D} 0 \% 9 \mathrm{~A} \% \mathrm{D} 0$ $\% \mathrm{~A} 0 \% \mathrm{D} 0 \% 98 \% \mathrm{D} 0 \% 9 \mathrm{C} \% \mathrm{D} 0 \% 86 \% \mathrm{D} 0 \% 9 \mathrm{D}$ $\% \mathrm{D} 0 \% 90 \% \mathrm{D} 0 \% 9 \mathrm{~B} \% \mathrm{D} 0 \% 86 \% \mathrm{D} 0 \% \mathrm{~A} 1 \% \mathrm{D} 0$ $\% \mathrm{~A} 2 \% \mathrm{D} 0 \% 98 \% \mathrm{D} 0 \% \mathrm{~A} 7 \% \mathrm{D} 0 \% 9 \mathrm{D} \% \mathrm{D} 0 \% 9$ E\%D0\%93\%D0\%9E\%20\%D0\%97\%D0\%9 0\%D0\%91\%D0\%95\%D0\%97\%D0\%9F\%D $0 \% 95 \% \mathrm{D} 0 \% \mathrm{~A} 7 \% \mathrm{D} 0 \% 95 \% \mathrm{D} 0 \% 9 \mathrm{D} \% \mathrm{D} 0 \% 9$ D\%D0\%AF.pdf

Gerasimov, R. (2010). Simulation in the investigation of crimes. Journal of Kyiv University of Law, No. 3, pp. $253-257$.

Gupta, S., Gupta, V., Vij, H., Vij, R., \& Tyagi, N. (2015). Forensic Facial Reconstruction: The Final Frontier. Journal of clinical and diagnostic research: JCDR, 9(9), ZE26-ZE28. https://doi.org/10.7860/JCDR/2015/14621.6 568

Grigorenko, A. O (2019). Reconstruction method as an innovative component of investigative activity. In the collection: Innovative methods and digital technologies in criminology, forensic science and legal practice of International "Round table" (Kharkiv, December 12, 2019). Kharkiv: Law, pp. 44 - 47. https://ivpz.kh.ua/wpcontent/uploads/2020/01/\%D0\%97\%D0\%B $1 \% \mathrm{D} 1 \% 96 \% \mathrm{D} 1 \% 80 \% \mathrm{D} 0 \% \mathrm{BD}-$ $\% \mathrm{D} 0 \% 9 \mathrm{~A} \% \mathrm{D} 1 \% 80 \% \mathrm{D} 1 \% 83 \% \mathrm{D} 0 \% \mathrm{~B} 3 \% \mathrm{D} 0$ $\% \mathrm{BB} \% \mathrm{D} 0 \% \mathrm{~B} 8 \% \mathrm{D} 0 \% \mathrm{~B} 9$

$\% \mathrm{D} 1 \% 81 \% \mathrm{D} 1 \% 82 \% \mathrm{D} 1 \% 96 \% \mathrm{D} 0 \% \mathrm{BB} \% \mathrm{D}$ $0 \% 86 \% \mathrm{D} 0 \% \mathrm{BD} \% \mathrm{D} 0 \% \mathrm{BD} \% \mathrm{D} 0 \% \mathrm{BE} \% \mathrm{D} 0 \%$ B2\%D0\%B0\%D1\%86\%D1\%96\%D0\%B9\% D0\%BD\%D1\%96-

$\% \mathrm{D} 0 \% \mathrm{BC} \% \mathrm{D} 0 \% \mathrm{~B} 5 \% \mathrm{D} 1 \% 82 \% \mathrm{D} 0 \% \mathrm{BE} \% \mathrm{D}$

0\%B4\%D0\%B8_2019-

$\% \mathrm{D} 0 \% 97 \% \mathrm{D} 0 \% \mathrm{~B} 1 \% \mathrm{D} 1 \% 96 \% \mathrm{D} 1 \% 80 \% \mathrm{D} 0$ $\%$ BD $\%$ D0\%B8\%D0\%BA.pdf

Jankowski, P. (2018). Crime Scene Reconstruction: Definition \& Uses. Study.com Retrieved from https://study.com/academy/lesson/crimescene-reconstruction-definition-uses.html.

Kiian, O. (2017). The concept and significance of forensic methods. [PDF file]. http://dspace.onua.edu.ua/bitstream/handle/1 1300/10725/Kiyn_O.B._Kiyn_T.M.\%20\%D 0\%A2\%D0\%BE\%D0\%BC\%202 2017178.pdf?sequence $=1 \&$ isAllowed $=\mathrm{y}$

Klymchuk, M., Marko, S., Priakhin, Y., Stetsyk, B., \& Khytra, A. (2021). Evaluation of forensic computer and technical expertise in criminal proceedings. Amazonia Investiga, 10(38), 204-211. https://doi.org/10.34069/AI/2021.38.02.20. https://amazoniainvestiga.info/index.php/am azonia/article/view/1558/1551 


\section{AMAZONIA \\ Investiga}

Kolodina, A. (2016). Principles of forensic methodology in the investigation of crimes. (PhD Dissertation). National University "Odesa Law Academy", Ukraine. http://dspace.onua.edu.ua/handle/11300/596

Law of Ukraine No. 4651-VI. Criminal Procedure Code of Ukraine. Official Web site of the Verkhovna Rada of Ukraine, April 13, 2012. Available online. In:

https://zakon.rada.gov.ua/laws/show/465117\#Text

Lukianchykov, B., Luk'ianchykov, Ye., \& Petriaiev, S. (2017). Forensics: A Study Guide for Students. Kyiv: National Technical University of Ukraine"Igor Sikorsky Kyiv Polytechnic Institute".

Luzhin, I. (1981a). Reconstruction in the investigation of crimes: textbook. Volgograd: publishing House of the Ministry of Internal Affairs of the USSR. http://lawlibrary.ru/izdanie6654.html

Luzhin, I. (1981b). Modeling in the investigation of crimes. Lib.sale. https://lib.sale/uchebnikkriminalistika/sledstvennayarekonstruktsiya-kak-raznovidnost108424.html

Martin, R. (1928). Textbook of anthropology: in a systematic presentation with special consideration of anthropological methods;

for students, doctors and research travelers. Jena:

Fischer. https://digital.zbmed.de/physische_anthropol ogie/content/structure/557542

Nehrebetskyi, V. (2018). The use of forensic reconstruction method during the investigative experiment. Entrepreneurship, Economy and Law, No. 5, pp. 253-257.

O'Hara, Ch. and O'Hara, G. (2003). Fundamentals of Criminal Investigation, Seventh Edition. Springfield (IL): Charles C. Thomas Publisher, Ltd.

Rathbun, T. (1984). Personal Identification: Facial Reproductions. Human Identification: Case Studies in Forensic Anthropology. Edited by Ted A. Rathbun and Jane E. Buikstra. Charles C. Thomas, Springfield, Illinois.

Ratinov, A. (1967). Forensic psychology for investigators. Moskow: NIiRIO VSh MOOP RSFSR. https://www.twirpx.com/file/989138/

Siegel, J. A. (2020, June 1). Forensic science. Encyclopedia Britannica. https://www.britannica.com/science/forensic -science

Tsilmak, O., ed. (2017). Modern methods of pretrial investigation of criminal offenses: a textbook. Odessa: Feniks.

Vasiliev, V. (2002). Legal Psychology. SaintPetersburg: Piter. 